\title{
CONTESTATION BETWEEN PURITAN ISLAM AND KEJAWEN IN THE URBAN YOGYAKARTA OF INDONESIA
}

\author{
Muhammad Arifin \\ Universitas Gadjah Mada \\ Email: aruneldalma@gmail.com \\ Irwan Abdullah \\ Universitas Gadjah Mada \\ Email: irwanabdullah6@gmail.com \\ Atik Tri Ratnawati \\ Universitas Gadjah Mada \\ Email: atik_triratnawati@yahoo.co.id
}

\begin{abstract}
Tensions between Puritan Islam and Kejawen Islam have never been resolved, despite various accommodation efforts. The ongoing contestation of the two traditions in Islam in Yogyakarta is because both always maintain strict cultural boundaries through symbols that represent their respective identities, be it in religious, art, cultural, economic and political practices. This study focuses on three aspects: (1) the form of representation of the contestation between Islam and Tradition (Kejawen) in the city of Yogyakarta; (2) the historical and cultural context which is the basis for the contestation between Islam and tradition; and (3) how the contestation between Islam and the Kejawen tradition is managed by each community in an effort to minimize the occurrence of social conflict between the two. Through these three aspects, this research aims to offer a new perspective in viewing the dialectical relations between Puritan Islam and Javanese (Kejawen) tradition contextually. The contestation between the Islamic tradition and the Kejawen tradition continued because of historical, political and global currents that provided space for both traditions to build their respective cultural identities.
\end{abstract}

Keywords: Contestation; Puritan Islam; Kejawen; Urban; Yogyakarta

\section{INTRODUCTION}

Tensions between puritan Islamic groups and Kejawen Islam have never been resolved despite various accommodation efforts. Each tradition is still strongly preserved, and even the cultural boundaries are increasingly strict. The Islamic symbol of Kejawen is emphasized through the tradition of wayang, 
slametan, nyadran, labuan offering, and gerebeg ceremony (Wahyono, 2003: 51). The Javanese tradition of Kejawen is referred to as one of the variants of Javanese Islam (Woodward, 1999), Mataraman Islam (Chalik, 2011: 269277), cultural Islam or ancestral religion (Maarif, 2017: 3; Wahyono, 2003: 51) whose teachings originate from tasawwuf which prioritizes mysticism (Sodikin \& Sumarno, 2013). Meanwhile, Puritan Islam (Wahyono: 2003) is referred to by experts as the reformist/modernist Islamic movement, tajdid movement (Zarkasy, 2013; Nashir, 2016: 16; Darban 2010). This tradition carries the notion that all actions in Islamic religious practice only refer to the Quran and the Sunnah of the Prophet Muhammad.

The current resistance between Puritan Islam and Kejawen is not only about monotheism, but also tensions and conflicts in the socio-cultural, economic and political sphere. In the socio-cultural space, for example, a form of tension that has surfaced recently, for example, the emergence of a letter allegedly coming from the Yogyakarta Mujahidin Council addressed to the Regent of Bantul which contains a rejection of the implementation of "Sea Alms". There was even destruction of the ritual properties for the implementation of the labuhan because it was deemed to deviate from the teachings of Islam (Mushrik). In addition, there was also an attack on the "Kerlap-kerlip Warna Kedaton" (Kedaton Color Twinkles) 2000" in Kaliurang Yogyakarta (Ahnaf and Hairus Salim, 2017).

Whereas in the political arena, contestation or disagreement is more common among social organizations affiliated with political parties that represent both traditions. For example Puritan Islam can be found in the Yogyakarta Islamic Community Forum (FUIY), the Ka'bah Youth Movement (GPK), Hamka, the Joxin Brigade and the Green Zone which are an underbow of the United Development Party (PPP). Whereas Javanese/Kejawen Islam can be found in the Tentara Langit and Red and White Cadets who are the underbows of the Indonesian Democratic Party of Struggle (PDIP). The forms of tension that occurred were physical clashes on the streets such as the clashes between supporters of the political parties in the 2019 elections in Jetak Hamlet, Ringinharjo Village of Bantul, namely between the PDIP vs. PPP masses. Even though these two groups are often in conflict, both groups are able to survive and continue to exist showing their identities in various social, cultural and political representations in the Yogyakarta public spaces.

So far, studies on the relationship between Islam and Kejawen have generally focused on two main issues, namely first, on the acculturation and assimilation of relations between Islam and local traditions (Geertz, 1960; Hefner, 1990; Woodward, 1999 \& 2011; van Bruinessen, 1994; Supena, 2012; Said, 2015; van 
den Boogert, 2015 and 2017). Second, studies that emphasize the oppression/ penetration of local culture by religion or by the state (Hefner, 1999; Abdullah, et al; Jubba, 2010, 2011; Suwardi, 2013; Iqbal \& Hairul Salim, 2017). It seems that the two study groups above have not touched on why and how the contestation between Islam (Muhammadiyah) and the Kejawen tradition continues in the midst of the lives of the Yogyakarta people who are known as a tolerant, harmonious and multicultural society.

Correspondingly, this article aims to demonstrate a different development by looking specifically at the ability of the Kejawen tradition to survive and even form a dynamic interaction between Islam in a city that continues to go through modernization. This study focuses on three aspects: (1) the form of representation of the contestation between Islam and Tradition (Kejawen) in the city of Yogyakarta; (2) the historical and cultural context which is the basis for the contestation between Islam and tradition; and (3) how the contestation between Islam and the Kejawen tradition is managed by each community in an effort to minimize the emergence of social conflict between the two. Through these three aspects, this research aims to offer a new perspective in looking at the dialectical relations between Puritan Islam and Javanese (Kejawen) contextually. This work is based on an argument that cities or regions that are considered tolerant, harmonious and multicultural do not have conflicts and tensions. Specifically, this article aims to show the opposite that tensions and disharmony exist in the form of political and cultural symbols and practices in the public spaces of Yogyakarta City.

\section{RELATIONS BETWEEN PURITAN ISLAM AND KEJAWEN TRADITION}

The study on relations between Puritan Islam and the Javanese tradition tends to be seen from an acculturation point of view only (Woodward, 1999 \& 2011; Sumbullah, 2012; Karimullah K, 2018; Muhammad Ali (2011); Bakri, 2014; Chakim, 2009; Muqoyyidin, 2012; Woodward, 1988). From existing studies, it appears that Javanese and Islamic traditions always go hand in hand to an extent that they even complement each othery. Nakamura's study of Muhammadiyah, especially in Kota Gede, Yogyakarta (located east of Kauman), in his book is additional research from what was done before. While the first edition puts more emphasis on historical anthropological inquiry, the second places more emphasis on anthropological ethnography, where the data were not merely written sources that are more historical in nature but were mostly base on the results of observations and interviews with Muhammadiyah figures who were personally built by Nakamura for years across generations. This approach is 
one of the strengths of Nakamura in his book, where his data and analysis are the result of dialog between research subjects and the researcher. It can be seen in his book how Nakamura portrays 'orthodox Islam' or 'Islamic orthodoxy' which can survive and even develop in a society that is influenced by predominant Javanese culture and tradition.

There are several findings put forward by Nakamura that corroborate his argument on how Islam (Muhammadiyah) which is a reformist Islamic movement actually grows and develops in the midst of the center of development and power of Javanese tradition. First, Nakamura saw a dynamic religious notion among Muhammadiyah members, who at a first glance when viewed from the outside seems very rigid, introverted, fanatical, and antiJavanese culture. But on the contrary, Muhammadiyah is very flexible, more tolerant, open and even in certain contexts njawani (of Javanese nature) (pp. 210-211). Second, Muhammadiyah in its development has received a lot of strong support from the people who actually have strong Javanese roots from various social classes, such as traders, farmers and even from the priyayis. And this can be seen until now in the fact that Muhammadiyah supporters come from various groups and diverse social strata (pp. 13-16). In its later development, Muhammadiyah cadres no longer come from traditional circles, but from relatives or kinship networks that have been built up through various religious organizations and strong forums.

There has been little research/attention on the relations between Puritan Islam and Kejawen as a contestation and conflicting relation which has been going on, especially in the city of Yogyakarta. This article seeks to see how dialectical relations between Islam and Kejawen are built through various discourses or conversations in the public spaces by placing religious symbols and practices and traditions as part of the ongoing contestation process. Expressions of religious and traditional identity through symbols, conversations, and social practices in the form of worship behavior, art performances, and mass mobilization are not only expressions of identity, but also appear as a form of affirmation of resistance or rejection of social norms between them.

\section{POLITICAL CONSTELLATION BETWEEN MODERNIST AND TRADITIONALIST ISLAM}

With regard to Indonesian Islam, Burhani (2013) indicates that there are two points of agreement between traditionalist and modernist Muslims regarding the building of unity between Islamic-ness and Indonesia-ness or Indonesian Islam. First, both sides accept Pancasila as a national ideology and nationalism as an ideal order for Indonesian Muslims. Second, in the manifestation of 
Islam in Indonesia, the context is different, although not necessarily unique. In addition, the two groups, namely the modernists and traditionalists, have a dispute at two points. First, traditionalists emphasize the uniqueness of Indonesian traditional culture as the basis of the unity of Indonesian Islam, while modernists tend to ignore this traditional culture. As a result, they respond differently to international influence. Second, traditionalists tend to emphasize national identity, while modernists place more weight on foreign achievements, sometimes at the expense of traditional heritage. Here, Burhani views Islam in the context of national or regional policy or political constellation by tracing this role historically.

Seeing the development of Islam in an organization that tends to be contradictory, for example between NU and Muhammadiyah, in addition to seeing the development of other Islamic organizations, James Fox (2004) has also reviewed historical developments. In his paper presented at Harvard Asia Vision, Fox views the development of the Islamic Organization by linking the development of Islam in Mecca and Egypt as a source of movement and the spread of religious ideology in Indonesia. Fox's conclusion in the paper is that the Islamic (contemporary Islam) movement in Indonesia is not just an ideological movement but is a political movement and has a democratic awareness through political channels.

Meanwhile, Bush (2002) not only explained the role of NU (Nahdhatul Ulama) in the political constellation of the State, but also described how NU was involved in contesting the discourse regarding Islamism, including the discourse of modernity and traditionalism, the post-traditionalist discourse with liberal Islam. In terms of tradition, $\mathrm{NU}$ accommodates the acculturation of local culture with Islam and is open to change. In relation to liberal Islam, there are some members of NU who are members of the JIL, but ideologically, NU separates itself from liberalism in Islam. NU still has a direction that is a reference in its movement. There are three principles that are consistently held by NU. First be critical autonomy vis a vis with the State. Second, NU is still on its way as a community organization, not wanting to be involved in practical politics. Third, NU will continue to proclaim the discourse of pluralism and tolerance both with fellow Muslims and with non-Muslims. NU's success in carrying out its movement was due to its openness with local cultures, so that it was easily accepted by the community.

Placing the position of Modernists vis-à-vis Traditionalists is also important in seeing how contestation occurs in this Kauman village. The majority of puritan groups are affiliated with Muhammadiyah with the emergence of a number of organizations such as Aisyiah, Suara Muhammadiyah, PKU 
Hospital, etc., which indicates the presence of this mass organization around Kauman. Meanwhile, placing traditionalists in this village also needs to remember in affiliation in general, NU has always been in a position to defend the local traditions, one of which is Kejawen, which is developing widely in this city. In general, Kejawen is affiliated with the NU organization.

\section{THE FORMS OF REPRESENTATION OF THE CONTESTATION}

The contestation that takes place between Islam and Tradition (Kejawen) often arises at various levels which are represented in various conceptions and manifestations. For example, contestation at the theological level related to the conception of God, epistemological with regard to the sources of teaching and truth, to the level of praxis or practice of life based on the conceptions built in each of these teachings. Descriptions of the various levels and manifestations of the contestation are evident in the following table 1.

Table 1: Forms of Contestation between Islam and Kejawen

\begin{tabular}{|c|c|c|}
\hline $\begin{array}{c}\text { Form of } \\
\text { Contestation }\end{array}$ & ISLAM & KEJAWEN \\
\hline \multirow[t]{2}{*}{ Concept of God } & $\begin{array}{l}\text { - God, Allah (the Cre- } \\
\text { ator) } \\
\text { - God exists and is One }\end{array}$ & $\begin{array}{l}\text { - Sangkan Paraning Dumadhi (from } \\
\text { where the servant of God comes and } \\
\text { returns) } \\
\text { - The reality of God is empty }\end{array}$ \\
\hline & $\begin{array}{ll}\text { - } & \text { Al Quran } \\
\text { - } & \text { The Prophet's Sunnah }\end{array}$ & $\begin{array}{l}\text { - Capitayan \& Jawa Dipa (Pelita } \\
\text { Jawa) } \\
\text { - } \quad \text { Sunan Kalijogo and Ranggawarsita }\end{array}$ \\
\hline $\begin{array}{l}\text { Doctrine } \\
\text { Resources }\end{array}$ & Reason/Logic & sense/spiritual \\
\hline $\begin{array}{l}\text { Sources of } \\
\text { Knowledge }\end{array}$ & $\begin{array}{ll}\text { - } & \text { Sahadat } \\
\text { - } & \text { Prayer } \\
\text { - } & \text { Fasting } \\
\text { - } & \text { Alms } \\
\text { - } & \text { Pilgrimage } \\
\text { - } & \text { Qur'an recitation } \\
\text { - } & \text { Tafakkur / wirid }\end{array}$ & $\begin{array}{ll}\text { - } & \text { Laku ritual } \\
\text { - } & \text { Tirakatan } \\
\text { - } & \text { Khaul/Ziyarah } \\
\text { - } & \text { Slametan/Kenduri } \\
\text { - } & \text { Nembang } \\
\text { - } & \text { Tapa/samadi }\end{array}$ \\
\hline $\begin{array}{l}\text { Norm and } \\
\text { Social organiza- } \\
\text { tion }\end{array}$ & $\begin{array}{ll}\text { - } & \text { Islamic Life Guidelines } \\
& \text { (PHI) } \\
\text { - } & \text { Hisbul wathon (scout) } \\
\text { - } & \text { Muhammadiyah Youth } \\
\text { - } & \text { KOKAM } \\
\text { - } & \text { Aisyiah \& Nasyiatul } \\
& \text { Aisyiah }\end{array}$ & $\begin{array}{ll}\text { - } & \text { Paugeraning Urip (life guideline) } \\
\text { - } & \text { Bergodho troops } \\
\text { - } & \text { Yogyakarta Community Alliance } \\
\text { - } & \text { Laskar Yogyakarta }\end{array}$ \\
\hline Economic & $\begin{array}{ll}\text { - } & \text { Islamic Banks, } \\
\text { - } & \text { Islamic economy } \\
\text { - } & \text { Ramadan Market }\end{array}$ & $\begin{array}{l}\text { - } \quad \text { Conventional Banks } \\
\text { - } \quad \text { Sekatenan Market } \\
\text { - } \quad \text { conventional market. }\end{array}$ \\
\hline
\end{tabular}




\begin{tabular}{|c|c|c|}
\hline Political & $\begin{array}{ll}\text { - } & \text { Islamic party affiliations } \\
\text { - } & \text { } \text { PPmely: } \\
\text { - } & \text { Youth Organizations } \\
\text { - } & \text { Political affiliation } \\
& \text { (Kaaba Youth Force } \\
\text { (AMK), } \\
\text { - } \text { Kaaba Youth Move- } \\
\text { ment } \\
\text { (GPK), Hamka Kau- } \\
\text { man, Yogyakarta Islam- } \\
\text { ic Community Forum } \\
\text { (FUI) and Laskar Joxin }\end{array}$ & $\begin{array}{ll}\text { - } & \text { Kejawen tends to be } \\
\text { - } & \text { affiliated with Golkar } \\
\text { - } & \text { and PDI } \\
\text { - } & \text { Youth Organization } \\
\text { - } \quad \text { political affiliation (Tentara langit, } \\
\quad \text { Taruna Merah Putih) }\end{array}$ \\
\hline
\end{tabular}

Source: Secondary data processing by researchers in 2019

The Table 1 shows that the contestation between Puritan Islam and Kejawen Islam takes place at various levels in social life, at the theological and philosophical levels and at the practical level. At the theological and philosophical levels, the contradictions are in the form of a conception of God and the sources or origin of teachings used as a way of life. Meanwhile at the level of praxis, the contradictions seem to take place at the level of religious behavior, community organizing through social and political organizations, to economic practices represented in economic institutionalization, such as banking, traditional markets, conventional markets, etc., as shown in the table 1.

\section{THE HISTORICAL AND CULTURAL CONTEXT OF THE EMERGENCE OF THE CONTESTATION}

The emergence of Muhammadiyah in Kauman Village, not only the emergence of a religious organization, but also the emergence of reform in the field of monotheism, worship and muamalah in Islam as discovered by Darban in his research in Kauman (2010: 34-40). This reform served as one of the grounds of the birth of Muhammadiyah, which emerged as an "Islamic Reform" movement within the Kauman, Keraton circles and Yogyakarta in general. It is in this context that the contestation of Islam, especially Muhammadiyah and Kejawen, actually began to emerge. Starting with a change in the direction of Qibla in the Gedhe Mosque, friction between the two traditions has already taken place. In the view of KH. Ahmad Dahlan as the founder of Puritan Islam (Muhammadiyah), the direction of Qibla does not lead to the Ka'bah which is the direction of the Qibla direction in the doctrine of Islamic beliefs, but rather to Africa. Therefore, the position must be changed. 
Another opinion related to the change in Qibla was also stated by MNC (60 years old) as follows:

"At that time, there was a phenomenon of TBC (Tahyul Bid'ah and Churafat), and this would be eradicated by Ahmad Dahlan. At that time, Muslims prayed facing west, not the Qibla, after checking with a map, it turned out that the west direction was facing Africa, to the Pyramid to the tomb of Pharaohs. Then Ahmad Dahlan changed the prayer position to Qibla by changing the lines of the Gedhe Mosque. With that event, he was scolded by many people, and he even was labeled as being insane. According to the residents of Kauman, it has been hereditary in the direction of prayer. He insisted and then moved to the family mosque; people were angry and the mosque was torn down; it was called a mosque of crazy people. Then, because he was alone there was not enough energy, then he needed a 'vehicle'. The 'vehicle' is Muhammadiyah organization “

There were many other changes in Kauman and around the Palace that occurred when Muhammadiyah was founded and opened contestation space. For example, changes in the santri learning system from the sorogan system, which is the system of taking turns reciting the Qur'an while sitting crosslegged to the classroom education system, to the change from the pesantren (santri) education system to public schools. At the same time, Muhammadiyah also preached and instilled its influence in the Palace and around Kauman Village with the principle of "Amar Ma'ruf and Nahi Munkar". It was intended to change the way of religion of the Kraton residents and Kauman Village in particular and the Yogyakarta Islamic Society in general who practiced the Kejawen Islamic tradition who believed in Takyul, Bid'ah and Churafat (TBC) which are considered to deviate from Islamic teachings. As stated by the MNC (60 Th) as follows:

"He saw Islam with all sorts of deviant things, worshiping God but still believing in amulets and all kinds, so he made an effort to restore Islam to its purest. At that time, TBC (Tahyul Bid'ah and Churafat) was widespread, and it would be eradicated by Ahmad Dahlan."

What the informant just said is one of the strong reasons why Muhammadiyah as a modernist movement or Islamic reform in the Keraton area and Yogyakarta in general was founded in addition to being a counter movement against the rise of current education and the influence of Christianization carried out by the colonial government at that time. Therefore, the birth of Muhammadiyah as a movement also carries the mission of community service in the field of 
health services and education.

Regarding education, as one of Muhammadiyah's missions, progressive changes to promote the Amar Ma'ruf and Nahi Munkar and the improvement of religious behavior are considered fundamental strategies. As stated by $\mathrm{Mr}$. $\mathrm{AF}$ (72 years old) as follows:

"Kyai Dahlan first wanted education, because he believed that education is an asset of the future. The literacy culture of Kyai Dahlan is that Kauman is said to have received a special karomah from God because of the emergence of Ahmad Dahlan. Speaking of literacy, children have been taught to read any text, to establish a school ... Kyai Dahlan taught numbers and letters and then the term "(pipolondo) ping poro lan suda" appeared. Kyai Dahlan's wearing kyai dress and using a blackboard and chalk in teaching is often considered infidel by other Kyais and Kauman residents. Other clerics had narrow insight, because they only used hijayyah letters in teaching, including writing Indonesian (they only knew Arabic pegon). They didn't know the alphabet"

The statement above shows that from the beginning, Muhammadiyah prioritized education for the younger generation. The data obtained by the Republika shows that the number of educational institutions owned by Muhammadiyah reached more than 10 thousand, or 10,381 to be exact. The details are shown in table 2 below.

Table 2. Number of Educational Institutions and Other Institutions owned by Muhammadiyah

\begin{tabular}{clc}
\hline No & \multicolumn{1}{c}{ Field of Activities } & Total \\
\hline 1 & Kindergarten / Qur'an Learning Center & 4.623 \\
\hline 2 & Elementary School (SD) / MI & 2.252 \\
\hline 3 & Junior High School (SMP) / MTs & 1.111 \\
\hline 4 & Senior High School (SMA) / SMK / MA & 1.291 \\
\hline 5 & Islamic boarding school & 67 \\
\hline 6 & Muhammadiyah College & 171 \\
\hline 7 & Hospital, Maternity Hospital, BKIA, BP, etc. & 2.119 \\
\hline 8 & Orphanage, Charity, Family Care, etc. & 318 \\
\hline 9 & Nursing home * & 54 \\
\hline 10 & Disability Rehabilitation * & 82 \\
\hline 11 & Special Schools (SLB) * & 71 \\
\hline 12 & Mosque * & 6.118 \\
\hline
\end{tabular}




\begin{tabular}{clcc}
\hline 13 & Islamic Prayer Room * & \multicolumn{2}{c}{5.080} \\
\hline 14 & Land $^{*}$ & 20 & $945.504 \quad \mathrm{M}^{2}$ \\
\hline
\end{tabular}

Source: http://www.muhammadiyah.or.id/content-8-det-amal-usaha.html

The Table 2 shows that educational institutions owned by Muhammadiyah throughout Indonesia are Educational Institutions from the most basic level up to tertiary institutions. In addition to general education institutions, there are also pesantren educational institutions, special schools, nursing homes and other public service facilities, such as hospitals. As for the Higher Education Institutions, to date Muhammadiyah has 171 units spread throughout Indonesia.

\section{THE POLITICAL CONTEXTS OF THE BIRTH OF THE CONTESTATION}

The long-standing contestation between Puritan Islam and Kejawen Islam is not only a contestation through the media and religious symbols and traditions but it also caused physical clashes between party supporters (specifically PPP who represented Puritan Islam) and PDIP (who represented Kejawen Islam) during the mass mobility of the regional head election campaigns and legislative and presidential elections. Based on several media reports, the clash between supporters of the Indonesian Democratic Party of Struggle (PDIP), which is referred to as the red or abangan party (Kejawen), and the United Development Party (PPP) or the so-called Green and Islamic party has been going on for a long time in Yogyakarta. The Tempo stated that physical conflicts between the two parties had been going on since 1999 during the legislative election, the regional head election and the presidential election until its peak in 2009. Detailed description of each physical contestation (physical conflict) is as follows.

1. The clash between the PDI-P and PPP supporters around the Beteng Wetan Corner in 2009.

2. Campaign clashes between PPP and PDIP on 5 April 2014 at Ngabean parking lot, Krapyak, Jogokaryan, south ring road to Krapyak

3. Clashes between the PDIP and the PPP supporters took place in Ngabean, Ngampil, Yogyakarta City. Location of the conflict was on Jalan Letjen Suprapto, PDIP supporters on the north side of the road, PPP on the south, June 4, 2014.

4. The clash between supporters of the parties participating in the 2019. The elections took place on Sunday (12/23) in Bantul, Yogyakarta. The clash 
between the PDIP and PPP supporters took place in Jetak Hamlet, Ringinharjo Village, Bantul.

These various physical conflicts or clashes are part of the many conflicts between party supporters in Yogyakarta, especially between the United Development Party (PPP) which represents the Puritan Islamic Party (Green Party) and the Indonesian Democratic Party of Struggle (PDIP) which represents the Abangan/Kejawen (Abang Party). These clashes indicated that the contestation not only toke place in the conceptual aspects and discourse, but also reached the physical level as shown in several cases above. Cases of physical conflict between the two camps carrying the ideology of Islam on one side and Tradition (Kejawen) on the other are phenomena that occur every year in several regions in the center and in other corners of Yogyakarta to other districts around it.

\section{THE EXISTENCE OF CUSTOMS AND LOCAL TRADITIONS IN THE SPECIAL REGION OF YOGYAKARTA}

Law Number 13 Year 2012 concerning the Special Region of Yogyakarta, covering 5 functions, namely How to Fill in the Position, Tasks, Duties and Authorities of the Governor and Deputy Governor; Institutional Affairs; Cultural Affairs; Land Affairs; and Spatial Affairs. Specifically in the authority of cultural affairs, Yogyakarta is increasingly given space to develop and reinforce local traditions or cultures that have become one of the characteristics of the city of Yogyakarta, as stated in Article 31 below.

(1) Cultural authority as referred to in Article 7 paragraph (2) letter $c$ is held to preserve and develop creations, tastes, initiatives and works in the form of values, knowledge, norms, customs, objects, arts, and noble traditions which is rooted in DIY society.

(2) Provisions regarding the exercise of cultural authority as referred to in paragraph (1) shall be regulated in Special Region Regulations.

Following the law, operationally regulated in Special Region Regulations, one of the forms of the strengthening is the existence of development funds. In the period of the 2018 fiscal year, Yogyakarta's special region funds increased to IDR 1 trillion, which was previously only around 800 billion. The increasing amount of the budget indicates that the Yogyakarta Regional Government is so concerned about local traditions and values. With this policy, the space for local customs and traditions to develop and exist is wide open.

Tourism is also very important to the special region of Yogyakarta. One of the 
tourism development packages in Yogyakarta is a cultural tourism package. This development is integrated into the Yogyakarta special region policy. With this policy, various cultural tourism programs in the form of traditions have strengthened. They, for example, are found in several programs below.

1. Promotion of sekaten and gerebeg as Yogyakarta tourist attractions,

2. The return of the tradition of bergodho and gunungan in the Yogyakarta's villages during the Independence Day celebration,

3. The emergence of dance groups and associations and rituals of offerings and labuh, nyadran especially when welcoming celebrations on major holidays, for example before the Eid Al Fitr and the Proclamation of Indonesian independence.

Tourism packages in the city of Yogyakarta are increasingly varied and growing along with the making of Yogyakarta as one of the tourist destinations. With the existing policies and financial support, it will further strengthen the position of local customs and traditions. This can be seen from the increasingly intense and rampant implementation and practice of traditions in Yogyakarta City, for example sekatenan, gerebeq, bergodo tradition, nyadran and local arts and culture festivals in each village.

\section{MANAGEMENT OF THE CONTESTATION}

There has not been specific effort made by Puritan Islam and Kejawen Islam in minimizing various conflicts that have occurred so far, except in a general context, namely between various religious and community life groups in Yogyakarta, various efforts have been made. They include, for example, the formation of "Forum for Religious Harmony (FKUB) in Yogyakarta through Governor Decree No. 20/KEP/2014, and the formation of the "Forum of Brotherhood of the Faithful (FPUB)" (Abduh, 2016). However, there are a number of fundamental attitudes and views that have taken place within each of the camps that have helped to ease the tension between them. They include, for example, the attitude of life in Kejawen, as confirmed by Mr. SE (55 years old) that «the Javanese are very flexible. They can adjust to any religion or belief. The point in Kejawen life is not to hurt the hearts of fellow humans, be it children, siblings, or neighbors. Kejawen is the principle of his life of peace and harmony." On the contrary, in the view of some community leaders in the Muhammadiyah, there is also a rather tolerant view, for example the views of Mr. MNC (60 years old) that "the tradition of the royal palace is merely tradition/culture, so there is no need to be allergic or too rigid in that respect. During traditional activities, the Kauman people can accept it. But if one uses the occult and offerings, that's what they reject." 
The change in attitude and tolerant outlook of the two contesting camps mentioned earlier increasingly emphasizes that there is still room and opportunity to manage the contestation so as not to cause widespread social conflict. Particularly in the Muhammadiyah camp, there is a more moderate and accommodative change in da'wah to the tradition, namely the cultural da'wah model as set out in the Muhammadiyah tanwir in 2002. The change in the da'wah paradigm is intended as a response to the dynamics and plurality of today's society (Hidayat, 2004 ; Al Hana, 2011), including in the city of Yogyakarta. Yogyakarta is already very famous for the many brandings that have been pinned by the local Government and its people. Starting from the branding "City of Students", "City of Gudeg", "Jogya Never Ending Asia", "Special Jogya" to "Yogyakarta Tolerant City". Branding as a tolerant city became very ironic when the 2018 Setara Institute report places Yogyakarta City in the 41st level of tolerance of 94 cities in Indonesia or is in the sixth position of index of cities with the lowest score of tolerance level. Even in a research report conducted by the UGM CRCS team in 2017 about the number of violence against minorities during the period 2000-2016, it shows that the number of violence or acts of intolerance in Yogyakarta is increasing (Iqbal \& Hairul Salim, 2017: 4 - 9).

What is shown by Iqbal \& Hairul Salim indicates that the occurrence of various cases of violence is the existence of opposition and rejection of social norms by certain social groups. At the same time, the phenomena of conflict as described in chapter three above emphasizes that the branding of Yogyakarta as a city of harmony, a multicultural city, is not a city that is safe and free from conflict and social tensions. But instead there is a struggle for identity values and social norms based on religion and tradition. In principle, this kind of struggle is not something new in Yogyakarta, but has been going on for a long time when the Islamic rebellion was born through the Muhammadiyah movement, and continues to this day because it continues to be reproduced socially through social practices by each of the contesting communities. In this context, it is exactly what was stated by Wiener (2017) that contestation is basically a social practice which is discursively an objection and rejection or disapproval of certain social norms by certain social groups. Attitudes and actions of contradiction or rejection here indicate an attempt to justify and reinforce values by certain groups, and at the same time reject, blame and even try to weaken the value system of other groups

Efforts to strengthen and weaken the values among the contesting camps tend to emerge through the symbolization of Islamic and Kejawen identities in public spaces. Symbolization that often appears in urban spaces as confirmed 
by Nas, Jaffe and Samuels, 2006 (in P.J.M Nas (ed), 2011: 9) is based on material, discourse, icons and behavioral symbol. These symbols are then accepted and manipulated in various ways (2006: 19). In the city of Yogyakarta, in particular, symbolic contestation, especially politically affiliated, tends to emerge through material, iconic and behavioral based symbols.

Furthermore, the existence of the Yogyakarta special region law can be seen as a form of contestation counteractive to the stream of Islamization that looks even stronger. The accommodation of local cultural heritage and the strengthening of its values is one of the central points emphasized in the special region law described above. The Yogyakarta palace which still exists today also shows that the symbolization of the Javanese values doctrine is very strong, where Nakamura argues that Islam (Muhammadiyah) which incidentally is a reformist Islamic movement grows and develops in the midst of the development and the power center of Javanese tradition in a way that is flexible. First, Nakamura saw a dynamic religious understanding and tolerance among Muhammadiyah members, who at first glance when viewed from the outside seem very rigid, introverted, fanatical, and anti-Javanese culture. But on the contrary, Muhammadiyah is very flexible, more tolerant, open and even in certain contexts njawani (of Javanese nature) (pp. 210-211). Second, Muhammadiyah in its development received a lot of strong support from the people who actually have strong Javanese roots from various social classes, such as traders, farmers and even from the priyayis. And this can be seen to date, Muhammadiyah supporters come from various groups and diverse social strata (pp. 13-16). In its later development, Muhammadiyah cadres no longer came from traditional circles, but from relatives or kinship networks created through various religious organizations and established religious forums. However, in many cases, the flexibility of Muhammadiyah in Yogyakarta is not always followed by the flexibility in the region. In many cases, Muhammadiyah very aggressively campaigns for "taklik, bid'ah and churafat (TBC) in regions.

\section{CONCLUSION}

The tensions between Puritan Islam and Kejawen have been going on for a long time and continue to be reproduced through political and cultural symbols. It has led to the puritanical Islam led by Muhammadiyah, which, in Nakamura's description, has become more flexible in its Islamic activism. The tensions are getting stronger because Kejawen as part of the tradition increasingly exists through tourism policies and affiliation with political organizations. The existence of the Yogyakarta Special Region Law further emphasizes the 
existence of Javanese teachings and culture manifested in various programs to strengthen Javanese arts and culture and this has become one of the forms of representation of the Puritan and Kejawen Islamic contestation in the public spaces. To bridge the conflict that might occur, in this context, the FKUB institution was founded which has indirectly become one of the institutions engaged in spreading messages of religious peace, as well as socializing them in society by considering the existing local traditions and culture.

\section{BIBLIOGRAPHY}

Abdullah, I. (2002). Simbol, Makna dan Pandangan Hidup Jawa: Analisis Gunungan pada Upacara Garebeg. Yogyakarta: Balai Kajian Seajarah dan Nilai Tradisional.

Ali, M. (2011). Muslim diversity: Islam and local tradition in Java and Sulawesi, Indonesia. IJIMS, Indonesian Journal of Islam and Muslim Societies, $1(1), 1-35$.

Bakri, S. (2014). Kebudayaan Islam Bercorak Jawa. Dinika, 12(2), 8.

Burhani, A. N. (2013). Defining Indonesian Islam An examination of the construction of the national Islamic identity of traditionalist and modernist Muslims in Islam in Indonesia: Contrasting Images and Interpretations (editor(s): Jajat Burhanudin, Kees van Dijk . Amsterdam University Press; 25-47.

Bush, R. (2002). Islam and Civil Society in Indonesia: the case of the Nahdlatul Ulama. Unpublished dissertation for the degree of Doctor of Philosophy, Department of Political Science University of Washington.

Chakim, S. (2009). Potret Islam Sinkretisme: Praktik Ritual Kejawen?, KOMUNIKA: Jurnal Dakwah dan Komunikasi, 3(1), 1-9. https://doi. org/10.24090/komunika.v3i1.110

Chalik, A. (2011). Islam Mataraman dan Orientasi Politiknya dalam Sejarah Pemilu di Indonesia. ISLAMICA, 1 (2), 269-277. https://doi. org/10.15642/islamica.2011.5.2.269-277

Darban, A. A. (2000). Sejarah Kauman: Menguak Identitas Kampung Muhammadiyah. Yogyakarta: Tarawang.

Fox, J. J. (2004). Currents in Contemporary Islam in Indonesia. Canberra: Research School of Pacific and Asian Studies. The Australian National University.

Howell, J. D. (2001). Sufism and the Indonesian Islamic Revival. The Journal of 
Asian Studies, 60(3), 701-729. https://doi.org/10.2307/2700107

Jochem, van den B. (2017). The role of slametan in the Discourse on Javanese Islam. Indonesia and The Malay World, 45(133, 352-372. https://doi. org/ 10.1080/13639811.2017.1345166.

Judith, J. (2017). Contesting Javanese Traditions. Indonesia and the Malay World, 45 (131), 3-23. https://doi.org/10.1080/13639811.2016.121949 4

Kholiq, A. (2013). Islam Kalang: Politik Identitas Sub Etnis Jawa. Harmoni, 12(1), 116-129.

Luthfi, K. M. (2016). Islam Nusantara: Relasi Islam dan Budaya Lokal. SHA$H I H$ : Journal of Islamicate Multidisciplinary, 1(1), 1-12. http://dx. doi.org/10.22515/shahih.v1i1.53.

Maarif, S. (2017). Pasang Surut Rekognisi Agama Leluhur dalam Politik Agama di Indonesia. Yogyakarta: : CRCS, Sekolah Pascasarjana UGM

Mulder, N. (1983). Abangan Javanese Religious. Bijdragen tot de Taal-, Landen Volkenkunde, Deel 139, 2/3de Afl. pp. 260- 267. https://www.jstor. org/stable/27863504.

Muqoyyidin, A. W. (2012). Dialektika Islam dan Budaya Lokal dalam Bidang Sosial Sebagai Salah Satu Wajah Islam Jawa, El Harakah, 14(1), 18-33. https://doi.org/10.18860/el.v0i0.2197

Musadad, A. N. (2018). Continuity and Change in Sundanese Pananyaa: Contesting an Islamicate Tradition in West Java. Jounal of Indonesia Islam, 12(01), 1-16. https://doi.org/10.15642/JIIS.2018.12.1.1-16

Nakamura, M. (1983), Bulan Sabit Muncul dari Balik Pohon Beringin: Studi tentang Gerakan Muhammadiyah di Kota Gede Yogyakarta. Yogyakarta: Gadjah Mada University Press.

Nashir, H. (2016). Muhammadiyah Gerakan Pembaruan. Yogyakarta: Suara Muhammadiyah Yogyakarta.

Nas, P. J. M. (Ed.). (2011). Cities Full of Symbols: A Theory of Urban Space and Culture. Leiden, Netherlands: Leiden University Press.

Nas, P.J.M., Groot, G.d. \& Schut, S. (2011). Introduction: Variety of Symbols in Nas, Peter J. M. (Ed.). (2011). Cities Full of Symbols: A Theory of Urban Space and Culture. Leiden, Netherlands: Leiden University Press, 7-26 pp.

Said, M. (2015). A Study on The Accuturation of Islam and Local Culture. Bungamale as a Local Culture of South Sulawesi. JICSA, 04(02), 77- 
100.

Sodikin, M. \& Sumarno, (2013). Sinkretisme Jawa-Islam dalam Serat Wirid Hidayat Jati dan Pengaruhnya Terhadap Ajaran Tasawwuf di jawa Abad Ke 19. AVATARA, e-Journal Pendidikan Sejarah, 1,(2), 308-319.

Sutarto, A. (2006). Becoming a true Javanese: A Javanese view of attempts at Javanisation, Indonesia and the Malay World, 34(98), 39-53. https:// doi.org/10.1080/13639810600650893

Sumpena, D. (2012). Islam dan Budaya Lokal: Kajian terhadap Interelasi Islam dan Budaya Sunda. Jurnal Ilmu Dakwah,. 6(19), 101-120. http://DOI: https://doi.org/10.15575/idajhs.v6i1.329

Sumbullah, U. (2012). Islam Jawa dan Akulturasi Budaya: Karakteristik, Variasi dan Ketaatan Ekspresif, el Harakah, 14 (1), 51-68. http://doi. org/10.18860/el.v0i0.2191

Wahyono, S.B. (2003). Kejawen dan Aliran Islam: Studi Tentang Respon Kultural dan Politik Masyarakat Kejawen Terhadap Penetrasi Gerakan Islam Puritan di Yogyakarta. Unpublished dissertation.

-------, (2001). Kejawaan dan Keislaman: Satu Pertarungan Identitas. Jurnal Ilmu Sosial dan Ilmu Politik, 5 (1), 41-60.https://doi.org/10.22146/ jsp.11107

Wiener, A. (2014). A Theory of Contestation. Heidelberg: Springer.

Woodward, M. R. (1988). The "Slametan": Textual Knowledge and Ritual Performance in Central Javanese Islam. in History of Religions, 28(1), 54-89. https://doi.org/10.1086/463136.

------, (1991). Javanism, Islam and the plurality of ethnography, Anthropological Forum, 6(3), 339-363, DOI: 10.1080/00664677.1991.9967417.

, (2001). Islam in Asia. International Encyclopedia of the Social \& Behavioral Sciences, 2nd edition, Volume 12. DOI: http://dx.doi.org/10.1016/ B978-0-08-097086-8.84015-5.

, (2009). Islamic and Religious Studies: Challenges and Opportunities for Twenty-First Century Indonesia. Journal of Indonesian Islam, 3(1). , (2011). Reflection on Java and Islam.1979-2010. Al-Jamíah, 49(2), 281-294. https://doi.org/10.14421/ajis.2011.492.281-294

Zarkasy, F. (2013). Tajdid dan Modernisasi Pemikiran Islam. Tsaqafah,9 (2), 395-418. http://dx.doi.org/10.21111/tsaqafah.v9i2.59 
Internet sources:

https://news.detik.com/berita-jawa-tengah

https://pojoksatu.id/news/berita-nasional/2018/12/24.

https://republika.co.id/berita-kiblat-masjid-gedhe-yogyakarta-miring.

http://www.muhammadiyah.or.id/content-8-det-amal-usaha.html

https://nasional.tempo.co/read

https://pemilu.tempo.co/read/568206/

https://daerah.sindonews.com/read/876711/22/

https://pojoksatu.id/news/berita-nasional/2018/12/24

https://news.detik.com/berita-jawa-tengah/Desember 2017/.

http://setara-institute.org/indeks-kota-toleran-tahun-2018

http://www.tribunnews.com/regional/2014/04/06/ 